\title{
Evaluation of Physicochemical, Nutritional and Sensory Quality Characteristics of New Papaya Hybrids Fruits Developed in JKUAT
}

\author{
Gaudence Nishimwe $^{1}$, Everlyn Musenya Okoth $^{2} \&$ Fredah Karambu Rimberia ${ }^{1}$ \\ ${ }^{1}$ Horticulture and Food Security Department, Jomo Kenyatta University of Agriculture and Technology, P.O. Box \\ 62000-00200, Nairobi, Kenya \\ ${ }^{2}$ Food Science and technology Department, Jomo Kenyatta University of Agriculture and Technology, P.O Box \\ 62000-00200, Nairobi, Kenya \\ Correspondence: Gaudence Nishimwe, Horticulture and Food Security Department, Jomo Kenyatta University \\ of Agriculture and Technology, P.O. Box 62000-00200, Nairobi, Kenya. Tel: 250-785-047-365. E-mail: \\ nigoshi121@yahoo.fr
}

Received: November 10, 2018

Accepted: November 28, 2018 Online Published: December 8, 2018

doi:10.5539/jfr.v8n1p12

URL: https://doi.org/10.5539/jfr.v8n1p12

\begin{abstract}
The world is faced with a lot of challenges including lack of sustainable development and inability to feed its growing population leading to malnutrition. The issue of accessing high quality nutritious foods such as fruits has become a major challenge for many African people. Papaya (Carica papaya L.) is among the most popular fruits grown in Kenya and excellent in nutritional content. However, its potential has remained unexploited due to inadequate quality planting materials, high post- harvest losses and prevalence of pests and diseases. Researchers at Jomo Kenyatta University of Agriculture and Technology developed promising papaya hybrids whose physicochemical, nutritional content and sensory characteristics have not been evaluated. Thus, the aim of this study was to determine the physicochemical, nutritional content and sensory quality characteristics of the new papaya hybrids and their control, Sunrise Solo. The physicochemical attributes evaluated included; total soluble solids, total titratable acid, $\mathrm{pH}$ and total soluble solid/total titrable acid ratio. While the nutritional content evaluated included (Vitamin $\mathrm{C}$ and $\beta$-carotene content) and sensory quality characteristics were evaluated. The standard AOAC methods was used to determine nutritional content and an effective analysis with 9- point hedonic scale was used on sensory evaluation. There was significant difference $(\mathrm{P}<0.05)$ in nutritional content of new hybrids papaya fruits and Sunrise solo. The maximum and minimum Vitamin C content of 131.63 $\mathrm{mg} / 100 \mathrm{~g}$ and $52 \mathrm{mg} / 100 \mathrm{~g}$ were exhibited by line 6 and 8 respectively. $\beta$-carotene content ranged between 1.69 and $3.39 \mathrm{mg} / 100 \mathrm{~g}$ as exhibited by line 1 and lines 2 and 8 respectively. The findings of this study revealed that the nutritional content of the new papaya hybrids exceeded the one of Sunrise Solo while their sensory quality characteristics compared favourably to the one of Sunrise Solo. Based on these findings, lines 1, 2,5,6,7 can be recommended for commercialization.
\end{abstract}

Keywords: Hybrids, papaya fruits, sensory, Vitamins

\section{Introduction}

The world is faced with a lot of challenges including lack of sustainable development and inability to feed its growing population leading to malnutrition (FAO, 2010). The population has been arising tremendously despite the stagnation in its food production (Godfray et al., 2010). The number of undernourished people in 2016 worldwide increased to an estimated 815 million up from 777 million in 2015, and the sub-Sahara Africa (SSA) remains the region with the highest prevalence of undernourishment (PoU) affecting $22.7 \%$ of its population in 2016 (FAO et al., 2017). The latest estimate for 2016 indicated that 155 million people below five years across the world were suffering from stunted growth, which may expose them to high risk of illness and poor cognitive skills (FAO et al., 2017).

Recent findings of Kenya demography and health survey have shown that one quarter of children less than five years are stunted because of malnutrition (KNBS and ICF, 2015). The issue of accessing high quality nutritious foods such as fruits has become a major challenge for many African peoples where the sub-Sahara Africa diets consist mainly of cereal and staple crops (Fanzo, 2012). Fresh fruits play a very significant role in human nutrition, especially as sources of vitamins, minerals and dietary fibre (Kader \& Yahia, 2011). It was reported by 
WHO (2003) that the world's demand for fruits will continue to increase in line with population expansion, rising standard of living, the awareness of the health benefits of fruits and up to 2.7 million lives could be saved annually with sufficient fruits and vegetables consumption (WHO, 2003). It was reported that development of fruits sector in developing countries has a positive impact on food and nutrition security and the households with fruits cultivation appear to have less nutrition-related health problems (Joosten et al., 2015). The strong growth rates in fruit cultivation and faster growing agricultural sub sector have been recorded in food-insecure and low-income regions such as SSA and Asia (Deribe and Mintesnot, 2016).

In Kenya, the most grown fruits are Banana, pineapples, Avocado, Papaya, Oranges, water melon, passion fruits and tamarillo and contribute $27 \%$ of total value of horticultural produce on Kenyan gross domestic product (HCD, 2016). There is potential for fruits growth due to the increasing demand both in domestic and export. However, the potential of the most fruits remain unexploited due to low adoption of modern technologies, inadequate quality planting materials, high post- harvest losses and prevalence of pests and diseases (HCD, 2016). Papaya (Carica papaya L.) is one of the tropical fruits with important antioxidant properties and also in great demand in international market (Laura et al.,2010). It is among the most popular fruits grown in Kenya. The recent ranking of fruits contribution to the Kenyan Gross domestic product (GDP), Papaya was ranked as the $6^{\text {th }}$ fruit of importance contributing $4 \%$ of the fruit's subsector (HCD, 2016). Regardless of income generation from papaya fruits, Rahman (2013) reported various benefits of papaya including, protection against heart diseases, promotes digestive health, anti-inflammatory effects, immune support, protection against macular degeneration, protection against rheumatoid arthritis, wound healing property and many industrial applications. Among papaya's distinguished nutritional characteristics, high levels of Vitamin A and C were reported, as well as being excellent source of sugars; glucose, fructose and sucrose compose a total of up to $13 \%$ of fresh fruits weight(de Oliveira \& Vitória, 2011).

The major challenges of papaya fruits production in Kenya as reported by (HCD, 2016), are lack of quality planting materials, low productivity, insect pests and diseases and lack of papaya seed producers. Researchers at Jomo Kenyatta University of Agriculture and Technology (JKUAT) developed new papaya hybrids from selection and cross pollination of different germplasms collected all over the country and Sunrise Solo (Rimberia et al.,2018). However, their physicochemical, nutritional content and sensory quality characteristics have not been evaluated in order to ensure their potential for commercialization. Thus the aim of this study was to determine physicochemical, nutritional content and sensory quality characteristics of the new papaya hybrids.

\section{Material and Methods}

\subsection{Papaya Fruits used for this Study}

Eight new papaya hybrids and Sunrise solo fruits (Figure. 1) were collected from JKUAT research farm situated in Juja ( $\left(1^{\circ} 5^{\prime} 29^{\prime \prime} \mathrm{S}, 37^{\circ} 0^{\prime} 39^{\prime \prime} \mathrm{E}\right.$ and 1521.3 meters above sea level), 36 kilometers northeast of Nairobi, Kenya 


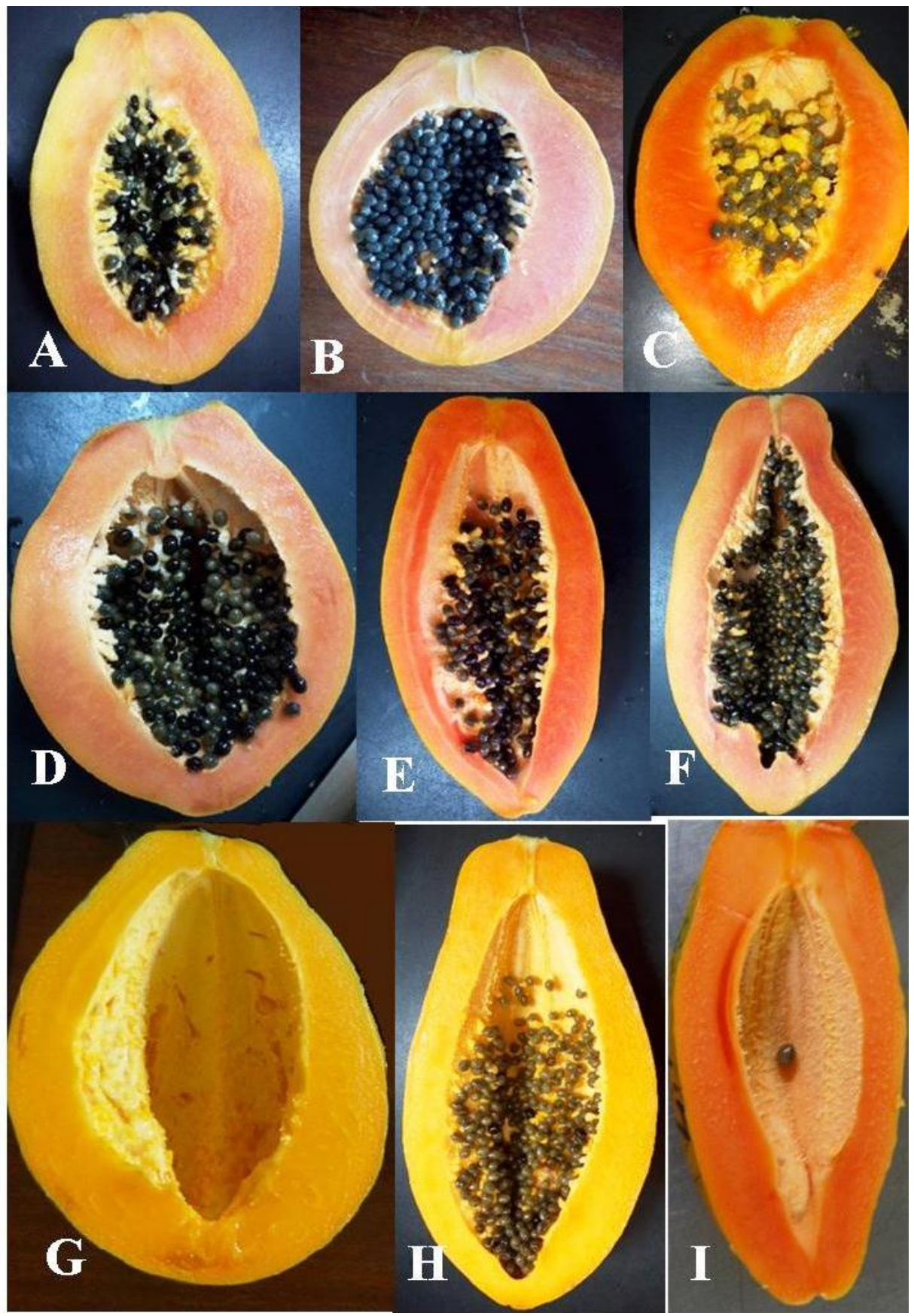

Figure 1. New papaya hybrids and Sunrise solo used in this study

A: Sunrise solo, B: Line 1 (MAN 1 X SUNRISE SOLO), C: Line 2 (VOI4 X ST2), D: Line 3 (VOI 5 X BLOCK A), E: Line 4 (VOI 5 X SUNRISE SOLO), F: Line 5 (MT/M7 X VOI 4), G: Line 6 (KIBBELEPTIC X SUNRISE SOLO0, H: Line 7 (VOI 4 X BLOCK A) and I: Line 8 (MAN 2 X SUNRISE SOLO)

\subsection{Experimental Design}

The experiment consisted of randomized complete blocks design with nine treatments (eight new papaya hybrid lines and Sunrise solo) replicated three times. The Sunrise solo is among the most commercially available variety grown in Kenya and it was used as one of the parental line during the development of these new papaya hybrids. Therefore, in this experiment it was used as the control. In each replication, one plant was selected randomly for each hybrid line and ten fruits were harvested from it at colour break stage for analysis. The papaya fruits were collected and evaluated between December, 2017 and February, 2018 from 11 months old female plants. 


\subsection{Chemical Reagents}

Phenolphthalein indicator, sodium hydroxide, standard ascorbic acid, Dichlorophenol indophenols (DCIPIP), Trichloroacetic acid (TCA), acetone, Petroleum Spirit, Anhydrous sodium sulphate and Silica gel of analytical grade were purchased from Lab link Supplies Nairobi

\subsection{Physicochemical and Vitamins Analysis}

\subsubsection{Total Soluble Solid Content (TSS)}

TSS content was determined as described by Mitcham et al. (1996).The \% brix was determined using an Atago hand refractometer (Model RX5000, Atago CO.LTD, Tokyo, Japan). A drop of homogenized papaya fruit juice was placed on cleaned prism of refractometer's prism, which had been calibrated and the lid closed. The TSS content was then read on a scale of the refractometer at $20^{\circ} \mathrm{C} \pm 1$ when held close to the eye. Between each reading, the refractometer was cleaned with distilled water and wiped with tissue paper.

\section{$2.4 .2 \mathrm{pH}$}

This was measured with a pH-meter (Hanna, HI $2211 \mathrm{pH} / \mathrm{ORP}$ meter) at ambient temperatures $\left( \pm 23^{\circ} \mathrm{c}\right)$. The standardization of $\mathrm{pH}$-meter with $\mathrm{pH}$ buffer solutions of 4.0 was done, the electrode was rinsed by distilled water and then standardized using the alkaline buffer solution of 9.18. Then the $\mathrm{pH}$ of the papaya fruits was measured.

\subsubsection{Total Titratable Acidity Content (TTA)}

The papaya fruits were homogenized using mortar and pestle to extract the juice. $0.3 \mathrm{ml}$ of phenolphthalein indicator was added to $10 \mathrm{ml}$ of clear juice of papaya fruits diluted by deionized water. The solution was then titrated against $0.1 \mathrm{~N}$ sodium hydroxide to a permanent pink colour and the results were expressed as a percentage of citric acid which is the main organic acid in papaya fruits as previously described by Mitcham et al (1996). The following formula was used.

$$
\mathrm{TA}=(\mathrm{ml} \mathrm{NaOH} \times \mathrm{N}(\mathrm{NaOH}) \times \text { acid meq.factor } \times 100) / \mathrm{ml} \text { juice titrated }
$$

\subsubsection{Ascorbic Acid (Vitamin C) Content}

This was determined by using 2, 6-dichlorophenol indophenols titration methods as described in (AOAC, 1996). Five grams of papaya fruit pulp was diluted with $10 \%$ Trichloacetic acid (TCA) in volumetric flask up to $100 \mathrm{ml}$. $10 \mathrm{ml}$ of diluted solution was titrated with 2, 6-Dichlophenolindophenol up to the pink colour. Percentage of ascorbic acid was calculated using the following formula.

$$
\text { Ascorbic acid }\left(\frac{m g}{100 g}\right)=(A-B) \times C \times\left(\frac{100}{S}\right) \times(100 / 10)
$$

Where $\mathrm{A}=$ Volume in $\mathrm{ml}$ of indophenol solution used in the sample

$\mathrm{B}=$ Volume in $\mathrm{ml}$ of indophenol solution used for blank

$\mathrm{C}=$ Mass in $\mathrm{mg}$ of ascorbic acid equivalent to $1 \mathrm{ml}$ of standard indophenol solution.

$\mathrm{S}=$ Weight of the sample taken $(\mathrm{g})$

$100 / 10=$ the total extraction volume/Volume of titrated sample

\subsection{5 $\beta$-carotene Content (Provitamin A)}

Determination of $\beta$-carotene was done using UV-VIS Spectrophotometer. Exactly $5 \mathrm{~g}$ of the sample was ground in mortar with pestle and gradual extraction was done with Cold Acetone up to $50 \mathrm{ml}$. After transferring the extract into $50 \mathrm{ml}$ volumetric flask using a glass funnel plugged with a small cotton wool, the sample was filtered and the residue was washed with cold acetone until devoid of colour. The partitioning with petroleum spirit was then performed after which sample was measured at $450 \mathrm{~nm}$ UV-Vis-spectrophotometer.

\subsection{Sensory Evaluation}

Sensory evaluation of the full ripe fruits samples under study was done using the 9- point hedonic scale (Lawless \& Heymann, 2010). The papaya pulp was separated from the skin and the seeds by knife and spoon, sliced and served to a panel of 30 members comprising staffs and students of JKUAT, belonging to the department of Horticulture and food security. Appearance, aroma, taste and sweetness were evaluated using a 9-hedonic point , where $(1=$ Dislike extremely; $2=$ Dislike it very much. $3=$ Dislike moderately; $4=$ Dislike it; $5=$ Neither like it nor dislike it. $6=$ Like it; $7=$ Like it moderately; $8=$ Like it very much; $9=$ Like it extremely).

\subsection{Statistical Analysis}


Data were subjected to a one way analysis of variance using GenStat software $14^{\text {th }}$ edition to assess any differences between commercialized hybrid (Sunrise Solo) and the newly developed hybrid lines. Statistical significance was determined at 0.05 and means were separated by the Duncan Multiple Range test.

\section{Result and Discussion}

\subsection{Physicochemical and Vitamins Content}

The results of physicochemical and vitamin content are shown in Table 1.

Table 1. Physicochemical and vitamins content of new papaya hybrid lines and Sunrise Solo

\begin{tabular}{lllllll}
\hline Treatment & $\begin{array}{l}\text { TSS } \\
(\% \text { brix })\end{array}$ & pH & $\begin{array}{l}\text { TTA } \\
(\%)\end{array}$ & $\begin{array}{l}\text { TSS/TTA } \\
\text { ratio }\end{array}$ & $\begin{array}{l}\text { Vitamin C } \\
(\mathbf{m g} / \mathbf{1 0 0 g})\end{array}$ & $\begin{array}{l}\boldsymbol{\beta} \text {-carotene } \\
(\mathbf{m g} / \mathbf{1 0 0 g})\end{array}$ \\
\hline Sunrise solo & $7.7 \pm 0.2^{\mathrm{c}}$ & $5.5^{\mathrm{b}}$ & $0.15 \pm 0.01^{\mathrm{c}}$ & $65.3 \pm 5.3^{\mathrm{d}}$ & $63.3 \pm 6.59^{\mathrm{cd}}$ & $2.91^{\mathrm{a}}$ \\
Line 1 & $11.2 \pm 0.1^{\mathrm{b}}$ & $5.5^{\mathrm{b}}$ & $0.18 \pm 0.01^{\mathrm{d}}$ & $65.2 \pm 2.5^{\mathrm{d}}$ & $63.03 \pm 7.24^{\mathrm{cd}}$ & $1.69^{\mathrm{c}}$ \\
Line 2 & $11.6 \pm 0.1^{\mathrm{b}}$ & $5.6^{\mathrm{a}}$ & $0.07 \pm 0.01^{\mathrm{ab}}$ & $163.6 \pm 6.6^{\mathrm{a}}$ & $76.6 \pm 0.74^{\mathrm{c}}$ & $3.39^{\mathrm{a}}$ \\
Line 3 & $8.7 \pm 0.2^{\mathrm{d}}$ & $5.5^{\mathrm{b}}$ & $0.16 \pm 0.01^{\mathrm{bc}}$ & $66.9 \pm 7.1^{\mathrm{d}}$ & $100.53 \pm 3.87^{\mathrm{b}}$ & $2.3^{\mathrm{b}}$ \\
Line 4 & $8.6 \pm 0.2^{\mathrm{d}}$ & $5.4^{\mathrm{bc}}$ & $0.09 \pm 0.01^{\mathrm{d}}$ & $111.3 \pm 6.4^{\mathrm{b}}$ & $79.37 \pm 4.55^{\mathrm{c}}$ & $2.02 \pm 0.57^{\mathrm{bc}}$ \\
Line 5 & $12.3 \pm 0.2^{\mathrm{a}}$ & $5.5^{\mathrm{b}}$ & $0.15 \pm 0.01^{\mathrm{c}}$ & $84.3 \pm 2.4^{\mathrm{c}}$ & $70.73 \pm 6.93^{\mathrm{c}}$ & $2.99^{\mathrm{a}}$ \\
Line 6 & $10 \pm 0.2^{\mathrm{c}}$ & $5.3^{\mathrm{cd}}$ & $0.16 \pm 0.01^{\mathrm{bc}}$ & $64.2 \pm 2.6^{\mathrm{d}}$ & $131.63 \pm 8.47^{\mathrm{a}}$ & $2.98 \pm 0.08^{\mathrm{a}}$ \\
Line 7 & $12.3 \pm 0.2^{\mathrm{a}}$ & $5.4^{\mathrm{b}}$ & $0.15 \pm 0.01^{\mathrm{c}}$ & $85.9 \pm 4.2^{\mathrm{c}}$ & $71.57 \pm 1.63^{\mathrm{c}}$ & $2.9^{\mathrm{a}}$ \\
Line 8 & $7.4 \pm 0.2^{\mathrm{e}}$ & $5.3^{\mathrm{d}}$ & $0.19 \pm 0.01^{\mathrm{a}}$ & $53.7 \pm 6.2^{\mathrm{d}}$ & $51 \pm 3.9^{\mathrm{d}}$ & $3.39^{\mathrm{a}}$ \\
LSD & 0.5 & 0.1 & 0.02 & 13.6 & 16.1 & 0.6 \\
CV\% & 10.6 & 3.5 & 29.4 & 31.6 & 11.8 & 12 \\
\hline
\end{tabular}

The data are expressed as means \pm standard error of the mean and the treatments means followed by the same letters in the same column are not significantly different ( $p \leq 0.05)$ (Zare, Orsat, \& Boye, 2015)

\subsubsection{Total Soluble Solids Content}

TSS of new papaya hybrid fruits ranged from 7.4 in line 8 to $12.3 \%$ in lines 5 and 7 . These results indicated that the new papaya hybrids could be used as dessert without any additive, and the hybrids with low TSS content could be used in the processing industry with sugar addition where necessary. This range obtained is greater compared to the range of $10.5-11.5 \%$ and 5.4- 9.6\% reported by previous researchers (Martin et al., 2011; Sancho et al., 2010). The results are in the range with the findings of (Fuggate et al., 2010; Schweiggert et al., 2012), which were $8-11.7 \%$ and $8.8-13.5 \%$ respectively. The wide variation in TSS content indicated that Lines 2,5 , and 7 have high sugar content that is more than the minimum of $11.5 \%$ required for papaya fruits. These hybrids lines are recommended for dessert consumption. The hybrids having the brix level lower than the minimum required, could be recommended for processing industry.

\section{$3.1 .2 \mathrm{pH}$}

$\mathrm{pH}$ ranged from 5.3 in lines 6,8 to 5.6 in line 2. There was significant difference $(\mathrm{P}<0.05)$ in $\mathrm{pH}$, between new papaya hybrids fruits $\mathrm{pH}$ and Sunrise Solo. The value of new papaya hybrids fruits pulp's $\mathrm{pH}$ obtained in this study were comparable to (5.3-5.5; 5.1-5.5 and 4.9-5.4) reported by previous researchers respectively (Emilie $e t$ al., 2005 ; Imungi \& Wabule, 1990; Schweiggert et al., 2012).

$\mathrm{pH}$ plays an important role in flavour promotion and preservation of fruit pulp ( Okoth et al., 2013). Low acid food products are characterized by $\mathrm{pH}$ value greater than 4.6 and less than 7.These products can be challenged by microorganism grow and multiplication, as well as bacteria's spore germination which result into product spoilage (Bockelmann and Von, 1998). Based on the findings of this study, both new papaya hybrids and Sunrise Solo felt into low acid class and careful handling and treatment should be adopted in order to reduce microorganism growth and spoilage.

\subsubsection{Total Titratable Acid (TTA)}

Among all evaluated papaya fruits, Line 2 had the lowest TTA of 0.07 while the highest $(0.19)$ was recorded in Line 8. Acidity in fruits is an important factor in determining maturity, it gives the total or potential acidity, rather than indicating the number of free protons in any particular sample. It is measure of all aggregate acids and sum of all volatile and fixed acids. The findings are not far from the range of $(0.07$ to 0.14$)$ reported by(O.N. de Jesus, J.P.X. de Freitas, 2013) and 0.09 to 0.019 obtained by (Schweiggert et al., 2012) on papaya fruits. The fruits acidity is determined by the type of organic acids it contains, the most predominant organic acid in papaya is citric acid. Citric acid accumulates during the second stage of development and during maturation, it generally 
decreases (Monselise, 1986). The reduction of the acidity associated to postharvest ripening has been attributed to the fact that organic acids are substrates for respiratory metabolism in detached products (Díaz-Mula, 2011). Thus the acidity in all evaluated papaya fruits was very low.

\subsubsection{TSS/TTA}

The mean TSS/TTA was maximum (163.6) in line 2 while the minimum (53.7) was recorded in Line 8. The ratio of TSS/TTA gives information on sugar/acid ratio balance in fruits. The high values above 100 observed in some hybrids lines were due to the typically low TTA levels and normal levels of TSS (Imungi and Wabule, 1990). The TSS/TTA ratio can be influenced by fruit variety and stage of ripeness. Since all evaluated hybrids were collected at the same stage of ripening, the significance difference observed in sugar/acid ratio could be due to varietal difference. The high value of TSS/TTA ratio in papaya fruits have been noted by previous researchers (Imungi and Wabule, 1990; Schweiggert et al., 2012).

\subsubsection{Vitamin C (Ascorbic Acid) Content}

There was significant difference $(\mathrm{P}<0.05)$ among the vitamin $\mathrm{C}$ value of new papaya hybrids and Sunrise Solo. The maximum vitamin $C$ of $131.6 \mathrm{mg} / 100 \mathrm{~g}$ was recorded in line 6 while the least of $51 \mathrm{mg} / 100 \mathrm{~g}$ was recorded in line 8 . The findings were comparable to those reported for papayas grown elsewhere such as $79-145 \mathrm{mg} / 100 \mathrm{~g}$ and 33-118mg/100g (Imungi \& Wabule, 1990 ; Bello and Enidiok, 2017) respectively. However, the levels of vitamin $\mathrm{C}$ founded in this study was greater than the range of $45.95-73.2 \mathrm{mg} / 100$ and $24.9-72.9 \mathrm{mg} / 100 \mathrm{~g}$ reported by(Manu et al., 2016; Schweiggert et al., 2012).

Vitamin C functions physiologically as a water-soluble antioxidant by virtue of its high reducing power. To provide antioxidant protection, the recommended dietary allowance (RDA) for adults for vitamin $\mathrm{C}$ is at $75 \mathrm{mg}$ /day for female and $90 \mathrm{mg} /$ day for male (Institute of Medicine, 2000). So far The DRA is defined as the average dietary intake level that is sufficient to meet the nutrient requirement of nearly (97-98\%) health individuals in a particular life stage and gender group (Food and nutrition Board, 2000). Based on the findings of this study, we can conclude that new papaya hybrids can contribute to more than the DRA in vitamin $\mathrm{C}$ content.

\subsection{6 $\beta$-carotene Content (Vitamin A)}

The new papaya hybrids and Sunrise Solo varied significantly $(\mathrm{P}<0.05)$ in their beta carotene content (Table 1$)$. The maximum was $3.39 \mathrm{mg} / 100 \mathrm{~g}$ exhibited by lines 2 and 8 , while the lowest recorded was $1.69 \mathrm{mg} / 100 \mathrm{~g}$ exhibited by line 1 . These values are greater than the range of $0.4-2.3 \mathrm{mg} / 100 \mathrm{~g}$ reported by (Imungi \& Wabule, 1990) while working on Kenyan papaya varieties. Consumption of papaya fruit is recommended for preventing vitamin A deficiency, a cause of childhood blindness in tropical and subtropical countries (Aikpokpodion, 2012). The new papaya hybrids are promising in reducing the prevalence of Vitamin A deficiency.

\subsection{Sensory Quality Characteristics of the New Papaya Hybrids Ripe Fruits}

Tables 2. Sensory quality characteristic of the new papaya hybrids fruits

\begin{tabular}{lllll}
\hline Treatment & Appearance & Aroma & Taste & Sweetness \\
\hline Sunrise solo & $7 \pm 0.16^{\mathrm{c}}$ & $6.63 \pm 0.15^{\mathrm{de}}$ & $6.48 \pm 0.18^{\mathrm{d}}$ & $6.55 \pm 0.18^{\mathrm{e}}$ \\
Line 1 & $8.28 \pm 0.1^{\mathrm{a}}$ & $7.83 \pm 0.14^{\mathrm{ab}}$ & $6.43 \pm 0.14^{\mathrm{d}}$ & $6.38 \pm 0.14^{\mathrm{e}}$ \\
Line 2 & $8.02 \pm 0.13^{\mathrm{ab}}$ & $7.63 \pm 0.15^{\mathrm{bc}}$ & $7.92 \pm 0.14^{\mathrm{a}}$ & $8.17 \pm 0.13^{\mathrm{a}}$ \\
Line 3 & $7.83 \pm 014^{\mathrm{b}}$ & $7.38 \pm 0.17^{\mathrm{c}}$ & $7.23 \pm 0.2^{\mathrm{b}}$ & $7.28 \pm 0.22^{\mathrm{bc}}$ \\
Line 4 & $7.9 \pm 0.16^{\mathrm{ab}}$ & $6.95 \pm 0.19^{\mathrm{d}}$ & $7.03 \pm 0.2^{\mathrm{bc}}$ & $7.13 \pm 0.17^{\mathrm{cd}}$ \\
Line 5 & $7.85 \pm 0.12^{\mathrm{b}}$ & $7.57 \pm 0.1^{\mathrm{bc}}$ & $7.42 \pm 0.13^{\mathrm{b}}$ & $7.55 \pm 0.12^{\mathrm{bc}}$ \\
Line 6 & $6.75 \pm 0.12^{\mathrm{c}}$ & $5.98 \pm 0,12^{\mathrm{f}}$ & $6.68 \pm 0.13^{\mathrm{cd}}$ & $6.75 \pm 0.15^{\mathrm{de}}$ \\
Line 7 & $7.68 \pm 0.13^{\mathrm{b}}$ & $8.2 \pm 0.09^{\mathrm{a}}$ & $7.38 \pm 0.14^{\mathrm{b}}$ & $7.72 \pm 0.13^{\mathrm{ab}}$ \\
Line 8 & $6.75 \pm 0.18^{\mathrm{c}}$ & $6.42 \pm 0.17^{\mathrm{e}}$ & $5.78 \pm 0.2^{\mathrm{e}}$ & $5.88 \pm 0.2^{\mathrm{f}}$ \\
LSD & 0.39 & 0.4 & 0.45 & 0.45 \\
CV\% & 14.3 & 15.7 & 18.2 & 17.9 \\
\hline
\end{tabular}

In this study organoleptic quality of the new papaya hybrid fruits were evaluated in order to help breeders to select the most liked hybrids and to ensure their commercialization. The results obtained are indicated on table 2, where appearance, aroma, taste and sweetness are respectively presented. There was significant difference $(\mathrm{P}<$ 0.05) in appearance, aroma, taste and sweetness among the new hybrids papaya and Sunrise Solo.

Based on appearance, line 1 and line 2 were liked very much. Line 7 was liked very much in regard of its aroma characteristic; while line 2 was liked moderately based on the taste. Among the all evaluated papaya hybrids, line 
2 was scored to be very much liked based on its sweetness.

The consumers buy fruits based on appearance and feel their satisfaction. Likelihood frequency of buying the fruits again depends on their perception of good eating quality (Kader, 2000). The fruits produce a range of volatile compound that make up theirs characteristic aroma and contributes to their flavour. Many of factors affect volatiles composition include the genetic makeup, degree of maturity, environmental conditions, postharvest handling and storage (El Hadi et al., 2013). Since all papaya fruits were grown in the same environmental conditions and harvested at the same maturity stage, the difference observed among them can be attributed to the genetic makeup.

\section{Conclusion}

This study showed that newly developed papaya hybrids fruits had superior nutritional content and Sensory quality characteristics. These findings will assist the breeders in selection of most performing papaya hybrids for commercialization and further improvement based on not only high yielding or resistance but also on nutritional and sensory potential. This study revealed that the nutritional content of the new papaya hybrids exceeded the one of Sunrise Solo while their sensory quality characteristics compared favourably to the one of Sunrise Solo. Based on these findings, lines 1, 2,5,6,7 are recommended for commercialization. The result of this study will contribute to increased fruits consumption, resulting in healthier and decreased micronutrient deficiency prevalence and gradual reduction of diseases resulting from lack of diversified diets.

\section{Acknowledgement}

The German Academic Exchange Service (DAAD) is acknowledged for the funding. The authors are grateful to the Africa Union-African innovation- JKUAT and PAUSTI (Africa -ai-JAPAN) for funding the project. The authors thank also Patrick Kavagi and Joyce Chepngeno for their guidance in the usage of equipments in the laboratory and JKUAT is acknowledged for provision of research facilities.

\section{References}

AOAC. (1996). Official Methods of Analysis. 16th Edition, Association of Official Analytical Chemist, Washington DC.

Bello, F. A. and Enidiok, S. . (2017). Effect of postharvest ripening stages on the nutritional compositions of pawpaw(Carica papaya) varieties. Nigerian Journal of Agriculture, Food and Environment., 13(2), 86-89.

Bockelmann., D. B. von B. and D. I. von. (1998). Long-Life Products: Heat-Treated, Aseptically Packed: A Guide to Quality.

de Oliveira, J. G., \& Vitória, A. P. (2011). Papaya: Nutritional and pharmacological characterization, and quality loss due to physiological disorders. An overview. Food Research International, 44(5), 1306-1313. https://doi.org/10.1016/j.foodres.2010.12.035

Deribe, H., \& Mintesnot, A. (2016). Review on Contribution of Fruits and Vegetables on Food Security in Ethiopia. Journall of Biology, Agriculture and Healthcare, 6(11), 49-58.

Díaz-Mula, H. M. (2011). Bioactive Compounds, Antioxidant Activity and Quality of Plum and Sweet Cherry Cultivars as Affected by Ripening On-Tree, Cold Storage and Postharvest Treatments.

El Hadi, M. A. M., Zhang, F. J., Wu, F. F., Zhou, C. H., \& Tao, J. (2013). Advances in fruit aroma volatile research. Molecules, 18(7), 8200-8229. https://doi.org/10.3390/molecules18078200

Emilie Proulx, M.Cecilia, N.Nunes, J. P. E. and J. K. B. (2005). Quality attributes limiting papaya postharvest life at chilling and non-chilling temperatures. Proc. Fla. State Hort. Soc, 118(May 2001), 389-395.

Fanzo, J. (2012). The Nutrition Challenge in Sub-Saharan Africa. UNDP - Regional Bureau for Africa - Working PAper, (January), 1-68.

FAO, IFAD, UNICEF, WFP, \& WHO. (2017). The State of Food Security and Nutrition in the World 2017. Building resilience for peace and food security. Fao, 1-109. https://doi.org/I4646E/1/05.15

Food and Agriculture Organization of the United Nations. (2010). The State of Food Insecurity in the World Addressing food insecurity in protracted crises 2010 Key messages. Notes. https://doi.org/10.1519/JSC.0b013e3181b8666e

Frank Joosten, Youri Dijkxhoorn, Y. S. and R. R. (2015). How does the Fruit and Vegetable Sector contribute to Food and Nutrition Security?

Fuggate, P., Wongs-aree, C., Noichinda, S., \& Kanlayanarat, S. (2010). Scientia Horticulturae Quality and 
volatile attributes of attached and detached 'Pluk Mai Lie' papaya during fruit ripening. Scientia Horticulturae, 126(2), 120-129. https://doi.org/10.1016/j.scienta.2010.06.019

Godfray, H. C. J., Beddington, J. R., Crute, I. R., Haddad, L., Lawrence, D., Muir, J. F., ... Toulmin, C. (2010). Food security: The challenge of feeding 9 billion people. Science, 327(5967), 812-818. https://doi.org/10.1126/science.1185383

Horticultural Crops Directorate (HCD). (2016). Validation Report 2015-2016.

Imungi, J. K., \& Wabule, M. N. (1990). Some chemical characteristics and availability of vitamin a and vitamin c from kenyan varieties of papayas (Carica papaya L.). Ecology of Food and Nutrition, 24(2), 115-120. https://doi.org/10.1080/03670244.1990.9991126

Institute of Medicine. (2000). Dietary Reference Intakes for Vitamin C, Vitamin E, Selenium, and Carotenoids. https://doi.org/10.17226/9810

Kader, A. A. (2000). Pre and postharvest factors affecting fresh produce quality, nutritional value, and implications for human health. Proceedings of the International Congress Food Production and the Quality of Life.

Kader, A. A., \& Yahia, E. M. (2011). Postharvest biology of tropical and subtropical fruits. Postharvest Biology and Technology of Tropical and Subtropical Fruits (Vol. 1). Woodhead Publishing Limited. https://doi.org/10.1533/9780857093622.79

Laura E. Gayosso-García Sancho, Sancho, E. M. Y. (2010). Effect of Maturity Stage of Papaya Maradol on Physiological and Biochemical Parameters. American Journal of Agricultural and Biological Sciences, 5(2), 194-203.

Lawless, H. T., \& Heymann, H. (2010). Sensory Evaluation of Food. https://doi.org/10.1007/978-1-4419-6488-5

Manu, T., Harminder, S., Jawandha, S. K., \& Gill, P. P. S. (2016). Assessment of nutrient composition of papaya cultivars grown under protected condition. International Journal of Agriculture Sciences, 8(54), 28222824.

Martin, R., Björn, C., Mora, E., Esquivel, P., \& Carle, R. (2011). Carotenogenesis and physico-chemical characteristics during maturation of red fl eshed papaya fruit ( Carica papaya L .). Food Research International, 44(5), 1373-1380. https://doi.org/10.1016/j.foodres.2011.01.029

Mitcham, B., Cantwell, M., \& Kader, A. (1996). Methods for determining quality of fresh commodities. Perishables Handling Newsletter, pp. 1-5. Retrieved from http://ucce.ucdavis.edu/files/datastore/234-49.pdf

National Bureau of Statistics-Kenya and ICF International. (2015). 2014 KDHS Key Findings. Rockville, Maryland, USA: KNBS and ICF International. (Vol. 6). https://doi.org/10.5261/2013.GEN1.04

O. Aikpokpodion, P. (2012). Assessment of genetic diversity in horticultural and morphological traits among papaya ( Carica papaya) accessions in Nigeria. Fruits, 67(3), 173-187. https://doi.org/10.1051/fruits/2012011

O.N. de Jesus, J.P.X. de Freitas, J. L. L. D. and E. J. de O. (2013). Use of morpho-agronomic traits and DNA profiling for classification of genetic diversity in papaya. Genetics and Molecular Research, 12(4), 66466663. https://doi.org/10.4238/2013.July.11.8

Okoth, E.M., Sila, D.N., Onyango, C.A., Owino, W.O., Musyimi, S.M. and Mathooko, F. M. (2013). Evaluation of chemical and nutritional quality attributes of selected mango varieties at three stages of ripeness, grown in lower Eastern province of Kenya - part 2. Journal of Animal \&Plant Sciences, 17(3), 2608-2618. Retrieved from http://www.m.elewa.org/JAPS;

Rahman, A. (2013). Health Benefits, Chemistry and Mechanism of Carica Papaya a Crowning Glory. Advances in Natural Science, 6(3), 26-37. https://doi.org/10.3968/g5167

Rimberia, F. K., Ombwara, F. K., \& Mumo, Naomi Nzilani, and E. M. A. (2018). Genetic Improvement of Papaya (Carica papaya L.). In: Al-Khayri J., Jain S., Johnson D. (eds) Advances in Plant Breeding Strategies. Fruits. Springer, Cham, 3, 897-928.

Schweiggert, R. M., Steingass, C. B., Esquivel, P., \& Carle, R. (2012). Chemical and morphological characterization of Costa Rican papaya (Carica papaya L.) hybrids and lines with particular focus on their genuine carotenoid profiles. Journal of Agricultural and Food Chemistry, 60(10), 2577-2585. 
https://doi.org/10.1021/jf2045069

World Health Organization ( WHO). (2003). Fruit and vegetable promotion initiative/a meeting report. GENEVA.

Zare, F., Orsat, V., \& Boye, J. I. (2015). Functional, Physical and Sensory Properties of Pulse Ingredients Incorporated into Orange and Apple Juice Beverages. Journal of Food Research, 4(5), 143. https://doi.org/10.5539/jfr.v4n5p143

\section{Copyrights}

Copyright for this article is retained by the author(s), with first publication rights granted to the journal.

This is an open-access article distributed under the terms and conditions of the Creative Commons Attribution license (http://creativecommons.org/licenses/by/4.0/). 